a także mieliśmy możliwość zobaczenia wielu ważnych poznawczo stanowisk neolitycznych tego obszaru. Organizując te warsztaty w okresie NRD narażała się dr Nagel na poważne kłopoty, ryzykując karierę zawodową własną i swego męża. Wielokrotnie też angażowała w te przedsięwzięcia własne, skromne przecież, środki finansowe.

Dr Erika Nagel była regularnym, czynnym uczestnikiem wszystkich liczących się konferencji naukowych dotyczących neolitu Polski zachodniej i północnej, służąc nawet pomoca w organizacji niektórych odbywających się w Polsce sesji międzynarodowych. Była m.in. de facto współredaktorem dwutomowej publikacji materiałów z konferencji „Die Trichterbecherkultur", która odbyła się w 1988 roku w Dymaczewie koło Poznania. Pracę tę wykonała społecznie, poświęcając swój urlop i nie zgadzając się nawet na umieszczenie jej nazwiska w notce redakcyjnej. Dopiero teraz mam okazję publicznie wyrazić jej za to uznanie i wdzięczność.

Dr Erika Nagel była uznanym specjalistą w zakresie neolitu północnoniemieckiego. Szczególnie bliska jej była problematyka kultury amfor kulistych, a jej prace z tego zakresu są często cytowane. $Z$ racji swych obowiązków redakcyjnych posiadała dobrą orientację także i w innych dziedzinach archeologii niemieckiej. Była wysoko kwalifikowanym, jednym z najlepszych redaktorów tekstów archeologicznych. Była także wiernym, oddanym przyjacielem, głęboko współczującym, zawsze na pierwszym miejscu stawiającym potrzeby innych, zawsze gotowym do pomocy. Była bardzo dobrą żoną i matką, starając się w wychowaniu córek w miarę możności niwelować negatywne skutki państwowego systemu wychowawczego. Swoją chorobę znosiła z podziwu godnym samozaparciem i odwaga. Nie ukrywała swojego stanu, ale nie dopuszczała do traktowania jej z tego powodu w sposób specjalny. Walcząc do końca z postępującą słabością starała się w miarę normalnie żyć, nie być nikomu ciężarem, nie pokazywać, jak jej ciężko. Była ogromnie wdzięczna Rodzinie, trwającej przy niej w najtrudniejszych chwilach i głównie o nią się troszczyła. Odchodziła zostawiwszy wszystkie sprawy uregulowane, pogodzona z sobą i światem. Swoją postawą wzbudzała wielki, powszechny szacunek.

Będzie nam Jej bardzo brakowało i na zawsze pozostanie w pamięci wszystkich, którzy Ją kiedykolwiek spotkali.

Dobrochna Jankowska

\title{
JUBILEUSZ 45-LECIA PRACY NAUKOWEJ PROFESOR ZOFII HILCZER-KURNATOWSKIEJ
}

W 1998 roku polskie środowisko archeologiczne obchodziło jubileusz 45-lecia pracy naukowej prof. dr hab. Zofii Hilczer-Kurnatowskiej. Uroczystość ta odbyła się na Ostrowie Lednickim dnia 4 czerwca 1998 r. i była połączona z sesją zorganizowaną przy pomocy Muzeum Pierwszych Piastów na Lednicy przez poznański Oddział Stowarzyszenia Naukowego Archeologów Polskich, którego Jubilatka jest współzałożycielką i animatorką. W tym uroczystym spotkaniu wzięli udział licznie przybyli z całej Polski przyjaciele, koledzy i uczniowie Pani Profesor; zaszczycił ją także swą obecnością biskup pomocniczy Archidiecezji Poznańskiej - ks. prof. dr hab. Marek Jędraszewski i opat klasztoru OO. Benedyktynów z Lubinia Wielkopolskiego - ojciec Kornel Filipowicz.

Obrady sesji pt. „Archeologia wielkopolska. Osiagnięcia i problemy ochrony zabytków” otworzył dyrektor Muzeum Pierwszych Piastów - mgr Andrzej Kaszubkiewicz. Przedmiotem 
wystapień na sesji były zasadniczo dwie kwestie. pierwsza z nich dotyczyła uregulowań prawnych związanych $z$ ochroną dziedzictwa kulturowego $w$ odniesieniu do archeologii. Tematyka drugiej części referatów obejmowała dokonania ostatnich lat $w$ zakresie badań terenowych na obszarze Wielkopolski. Obrady zamknęło niezwykle interesujące wystapienie Jubilatki, podsumowujące badania nad początkami państwa piastowskiego. Materiały z tej sesji ukażą się drukiem dzięki wsparciu finansowemu generalnego konserwatora zabytków.

Druga część dnia wypełniły uroczystości jubileuszowe. Rozpoczęła je laudacja wygłoszona przez niżej podpisaną, która przypomniała zebranym liczne, nie tylko czysto naukowe dokonania Pani Profesor na niwie archeologii, i w imieniu zespołu redakcyjnego wręczyła Jubilatce księgę pamiątkową pt. Kraje stowiańskie w wiekach średnich. Profanum i sacrum. Na tę imponujących rozmiarów pracę zlożyło się 68 artykułów autorów z Czech, Niemiec, Polski, Rosji, Rumunii, Słowenii i Ukrainy, nie tylko archeologów, ale też historyków i przyrodników. Pochwałę Jubilatki w serdecznych słowach wygłosiła prof. dr hab. Teresa Jakimowicz i prof. dr hab. Lech Leciejewicz; odczytano też nadesłane życzenia. Część oficjalną zakończyło wystapienie Profesor Zofii Kurnatowskiej, z pełną ciepła i przewrotnego humoru refleksją nad przebytą drogą zawodową. Piękna pogoda i miejsce obchodów - wyspa na Jeziorze Lednickim - było znakomitą oprawą dla tego koleżeńskiego spotkania, zakończonego wieczorem wspólnymi śpiewami przy ognisku.

Hanna Kóčka-Krenz

\section{ARCHIWUM PRYWATNE PROFESORA JÓZEFA KOSTRZEWSKIEGO}

W czerwcu 2000 roku Instytut Prahistorii UAM w Poznaniu nabył drogą kupna, od spadkobierczyni Profesora, resztkę Jego archiwum prywatnego.

Zbiór ten składa się z rękopisów i druków (ponad 100 pozycji tworzących 13 grup tematycznych). Na szczególną uwagę zasługują:

- korespondencja Profesora z Żona, z okresu okupacji hitlerowskiej,

- korespondencja oświęcimska Przemysława Kostrzewskiego - syna Profesora, z Matka,

- dokumenty dotyczące budowy domu w Strzeszynku,

- ekslibrisy,

- korespondencja abpa Antoniego Baraniaka, metropolity poznańskiego,

- dyplom Komandorii Orderu Sw. Grzegorza Wielkiego,

- dyplomy doktoratów honoris causa,

- korespondencja z prof. Konradem Jażdżewskim i innymi archeologami łódzkimi.

W celu zapewnienia archiwaliom należytego bezpieczeństwa, a także $w$ intencji scalenia materiałów po śp. Profesorze i tym samym lepszego włączenia ich do obiegu naukowego, Instytut Prahistorii UAM przekazał swą własność - w formie długoterminowego depozytu do Archiwum PAN w Poznaniu (sygnatura P. III - 51). 